\title{
Terima kasih kepada mitra bebestari pada tahun 2018
}

\section{Editor ARSHI Veterinary Letters}

Rumah Sakit Hewan Pendidikan Lantai 2, Gedung RSHP, Fakultas Kedokteran Hewan, Institut Pertanian Bogor. Jalan Agatis, Kampus IPB Dramaga, 16680, Bogor, Jawa Barat INDONESIA

EDITORIAL: Proses telaah naskah dalam suatu jurnal ilmiah merupakan hal yang sangat penting untuk penjaminan mutu kualitas yang terbaik atas naskah yang dipublikasikan. Naskah yang telah berhasil dipublikasikan pada tahun 2018 berjumlah 40 dengan jenis tulisan studi kasus 26 naskah, 13 naskah hasil penelitian, dan 1 naskah tentang catatan teknis. Editor mengucapkan banyak terima kasih kepada para mitra bebestari atas kerjasama, curahan waktu, dan dedikasinya yang diberikan untuk eksistensi jurnal ini pada tahun 2018 lalu, yaitu:

Erwin, ;

Lestari, Citra Ayu;

Noviana, Deni;

Sudisma, I Gusti Ngurah;

Ulum, Mokhamad Fakhrul;

Winarso, Aji.

Kata kunci:

editorial, mitra bebestari, terima kasih 